\title{
Governance, Good Governance, Organized Leadership and Meaningful Development: The Nigerian Experience
}

\author{
Adamson, Duncan Ganiyu (Corresponding Author) \\ Department of Political Science, Faculty of Social Sciences, University of \\ Lagos, Akoka - Yaba Lagos, Nigeria \\ E-mail: duncan7457@gmail.com
}

\begin{abstract}
Halima A. Godowoli
Department of Political Science, Faculty of Social Sciences, University of Maiduguri,

Maiduguri, Borno State, Nigeria

E-mail: halimahaabs@gmail.com
\end{abstract}

Lawal, Joy Oritesedurotimi

Department of Political Science, Faculty of Social Sciences,

University of Lagos, Akoka -Yaba Lagos, Nigeria

E-mail: joytimi@yahoo.com

Received: Jan. 21, 2018 Accepted: Feb. 17, 2018 Online published: Mar. 7, 2018

doi:10.5296/jpag.v8i1.12519

URL: https://doi.org/10.5296/jpag.v8i1.12519

\begin{abstract}
This paper discusses how the process of governance in Nigeria over the years has been characterized by many negative indications, while the world which our government is pretending to copy is fast entrenching in every facet of its laws and practices the sanctity of life. It also discusses how our electoral and political machinery are legitimizing murder as an acceptable paradigm of settlement of even minor brushes. Governance is supposed to be articulate and organized leadership to culminate meaningful development that will bring the greatest happiness for the greatest number of people. Methodologically, the study was carried out using content analysis. Various existing document such as, historical evidence, newspaper
\end{abstract}


reports, journal and existing archival records were content analyzed. Thus, while democracy in Nigeria is but a sham, good governance is still far in coming. The paper found out that the political class has continued to dispose and demonstrate known military attribute like corruption, civil authoritarianism, democratic dictatorship, brazen disrespect for human life, which have led to incessant killings as a political strategy. Rather than produce good governance that will develop the State, the above scenario has produced bad governance and further increased the poverty of the Nigerian populace. The paper recommended a general reconstruction of Nigeria's political, social and economic infrastructure.

Keyword: governance, good governance, democracy, corruption, leadership

\section{Introduction}

The essence of government in every society is the creation of necessary enabling environment for the facilitation of good life and universal acceptance of democracy as the best system of governance is incontestable (Mato, 2005: 105; Leke, 2010: 32). The need to protect and ensure life and survivability brought about the state. The social contract theory of the State clearly explains why man in the first place decided to surrender some essential components of his liberty and freedom to a committee of persons for the purpose of defence of life and security (Thomas Hobbes's State of Nature).

The essence of modern governance has transcended the desire for security against physical or military aggression to defence against basic social and economic insecurity. The right to choose who leads in any society is a principal ingredient in what is today referred to as democracy (Mato, 2005: 105).

The Nigerian State has witnessed increasing buildup of authoritarian structure and institutions as well as human right abuses. The resultant unstable political atmosphere has continued with poor social infrastructure to frighten off local and foreign investors (Leke, 2010: 32).

As Frantz Fanon has aptly observed, there is nothing but a fancy dress parade and the blare of trumpet. There is nothing except a few reforms at the top while at the bottom the masses are still endlessly marking time (Fanon, 1965: 65). The above analysis by Fanon can be likened to Nigerian situation.

It is sad that despite Nigeria being a sovereign state for over 57 years, with an abundance of natural resources at the country's disposal, the lives of the Nigerian populace has not been transformed as a result of bad and inept leadership that have always been at the helm of affairs. Some scholars even predicted that if the leadership remains the same "Nigeria would be a failed State by the year 2020". Although it is not within the scope of this paper to give the parameters of a failed state, it is however pertinent to say that Nigeria exhibits the characteristics of a failed state.

The question now is, what has independence brought us? As Nigeria gets older, are we making any progress in the areas that define governance, leadership, human and infrastructural development? With the end of military rule, has democratic rule brought the greatest happiness for the greatest number of people as described by Jeremy Bentham? Are 
the people happy with the way the country is being governed?

From the analysis above and with the benefit of hindsight, this paper attempts to answer the questions against the backdrop of the foregoing. What we intend to do in this paper is to look at some conceptual clarifications, and proceed at examining some indicators of governance in Nigeria; corruption, democratic dictatorship, economic failures and decayed infrastructural facilities. In the last segment of the paper, we will discuss the nature of governance in Nigeria today. This paper ends by drawing a logical conclusion and making recommendations.

\section{Research Methodology}

Methodology is a research strategy that translates ontological and epistemological principles into guidelines that show how research is to be conducted (Sarantakos, 2005), principles, procedures, and practices that govern research.

Thus, in this paper, governance, good governance and organized leadership in Nigeria were investigated. In this study, relevant historical evidences, newspaper reports, books, journals and existing archival records were collected and content-analyzed, in order to be able to answer the research questions.

\section{Conceptual Clarification}

Terms like governance and good governance, democracy, leadership and development are hereby explained for clarity;

\subsection{Governance}

Governance is defined by the World Bank as "the manner in which power is exercised in the management of a country's economic and social resources for development”. Good governance will in effect mean the use of power by the government i.e. the President and Ministers, Senators, House of Representatives and how the Public Service operates: to promote democracy, accountability and transparency, to formulate and implement good policies and to effectively and efficiently manage the Nigerian human and financial resources in order to achieve sustainable national development, economic prosperity and to alleviate poverty (Yahaya, 1999: 15).

The achievement of the objectives of good governance is heavily dependent on the caliber and orientation of the political leaders in government and a competent, well trained and motivated public service. Hinging on the World Bank definition, it is obvious that good governance can be guaranteed on a platform of plural democratic system and a public service that can work and achieve results.

Good governance becomes very fundamental and imperative when viewed against the backdrop of massive deterioration of government institutions, pervasive poverty and alarming unemployment rate, corruption, as well as near total collapse of moral and ethical standards engendered by nearly three decades of military rule in the country, which saw governance capacity weakened at all levels (World Bank, 2004; Ujomu, 2004). It should be noted that the same characteristics and traits exhibited by the military continued under democratic 
dispensations.

\subsection{Leadership}

Leadership is distinct a concept from rulership. The former connotes showing the way. In other words, leadership constitutes a guide, an indication, a direction, just as it provides the led with the desirables in, and of, charting a course and new direction. Stodgill (1981: 7) observes that many of the attempts to define leadership are "confusing, varied, disorganized, idiosyncratic, muddled, and according to conventional wisdom quite unrewarding". However, we can build our explanation on the concept of leadership around the etymological interpretation, which sees the leader as that individual who directs by going in front (quoted in Yagboyaju, 2004: 148).

Simply put, the leader is someone who lays an example for others to follow. In this way, leadership implies a purposeful direction of the affairs of those led. Put differently, a leader is a true representative of the people, consciously and conscientiously chosen by the led, (without undue influence or coercion) and given the necessary political power and authority (Olanipekun, 2004). Therefore, a leader, like magnet, radiates aura which attracts the people. The relationship between the duo, that is, the leader and the led, attract each other.

Contrary wise, a ruler, therefore, radiates heat or fire which consumes his subjects over whom he dominates, a relationship or scenario which favourably and justifiably cannot attract each other.

We believe that leadership is a better institution notion than rulership. The exercise of leadership if pursued vigorously and according to its tenets and goals, should ensure the attainment of Jeremy Bentham's dictum which recommended for any modern government, "greatest happiness for the greatest number of people".

From the foregoing analysis on leadership and rulership, it can be gleaned that leadership is arguably a better and preferred institution which aspires to achieve greatness. Nigeria continues to be bedeviled by the problem of leadership; hence fifty seven years after independence, Nigeria is still being ingloriously ranked among the poorest nations of the World. No thanks to inept, visionless, rumbustious leadership.

Achebe (1983: 1) graphically captured the problem of Nigeria, in the following memorable words;

It is total false to suggest, as we are apt to do, that Nigerians are fundamentally different from any other people in the world. Nigerians are corrupt because the system under which they live today makes corruption easy and profitable; they will cease to be corrupt when corruption is made difficult and inconvenient... The trouble with Nigeria is simply and squarely a failure of leadership. There is nothing basically wrong with the Nigerian land or climate or water or air or anything else. The Nigerian problem is the 
unwillingness or inability of its leaders to rise to the responsibility, to the challenge of personal example which is the hallmark of true leadership...

These lines are as true of Nigeria today as they were written some thirty two years ago. Olanipekun (2004) observes that, the absence or total lack of leadership in the country has consistently resulted in growing state of insecurity, absence of requisite basic social infrastructure, unemployment, corruption, grave economic predicament and uncertainty (which has made Nigeria a debtor and a beggar nation), inadequacy of food at reasonable and affordable prices, inflation of unimaginable proportion, health services that are in shambles, hospitals that have been reduced to mere consulting clinics etc. It is an irony that most of those who have only succeeded in running the country aground are now consciously or unconsciously being recycled or "sanitized" to continually lord it over us in one capacity or the other and this explains why we are not making much progress.

\subsection{Development}

Gauba (2003) conceives development as the increasing capacity to make rational use of natural and human resources for social ends. According to Olukoju (2013), development is a historical process through which human beings choose and create their future within the context of their environment to achieve a humanist and creative society. It is concerned with the dignity of the individual, that level of self - awareness that is secure and self - accepting and the restructuring of the institutions.

Todaro (1985: 85) defines development as a multidimensional process involving major changes in social structures, popular attitudes and national institutions, as well as the acceleration of economic growth, the reduction of inequality, and eradication of absolute poverty. Development, in its essence, must represent the whole gamut of change by which an entire social system tuned to the diverse basic needs of individuals and social groups within that system, moves away from a condition of life widely perceived as unsatisfactory and toward a situation or condition of life regarded as materially and spiritually better.

However, as argued by Todaro, while economic progress is an essential component of development, it is not the only one. Development on the other hand encompasses more than the financial and material side of people's lives. Todaro believes that there are three core values of development and these core values are life sustenance, self-esteem and freedom to choose.

Human beings constitute the fulcrum on which development revolves. Walter Rodney views Marxists expositions on development as follows:

Development in human society is a many sided process. At the level of individual, it implies increased skill and capacity, greater freedom, creativity, self-discipline, responsibility and material well being. At the level of social groups, it implies an increasing capacity to regulate both internal and external relations (Rodney, 1972). 
To the Marxists the idea of development revolves around Man. Thus, at the individual level, human beings are seen as the epicenter of development.

Thus, development encompasses the physical, material and spiritual changes in the society which produce consistent improvements in the wellbeing of the people. But while the steady and consistent growth of the economy, improvement in life style, educational standards and technology are quantifiable and measurable, intangible things such as emotional well-being cannot quantified. Hence, development is relative, contextual and non-linear (Olukoju, 2013).

\subsection{Democracy}

That government of the people, by the people, and for the people, shall not vanish from this earth - (President Abraham Lincoln, 1863, quoted in Dauda and Liman, 2005:107).

This famous definition of the concept of democracy has remained the most widely accepted meaning of democracy within liberal scholarship and public opinion.

Democracy is most meaningful with regular free and fair elections which enable the people to choose their representatives and by so doing the people can hold their rulers accountable and replace a non-performing government. In addition, electoral democracy creates the opportunity for the people to monitor and also express their policy preferences (Fadakinte, 2013).

Democracy as a system of government is no doubt and perhaps the most complex and difficult of all forms of government. It is filled with tension and contradictions; it requires that its members labour diligently to make it work. Democracy is not necessarily designed for efficiency, but for accountability; a democratic government may not be able to act as quickly as a dictatorship but once committed to a course of action it can draw upon deep well spring of popular support. Democracy certainly in its American form is not a finished product, but it is always evolving (Mato, 2005: 107).

Ake (1991) observes that democracy repudiate arbitrariness and authoritarianism. It extols the consent of the governed and it protects human personality and values. Democracy whether liberal or African or modern includes fundamental recognition of popular sovereignty, equal opportunity for all, majority rule, representativeness, minority rights, right of choice between alternative programmes, popular consultation, consensus on fundamental issues and more essentially periodic elections (Oke, 2005: 45).

According to Thomas Jefferson, "Democracy is cumbersome, slow and inefficient, but is due in time. The voice of the people will be heard and their latent wisdom will prevail". The same Thomas Jefferson in a speech delivered in Maryland in 1809 said that "The care of human life and happiness, and not their destruction, is the first and only legitimate object of good government". Plato in his "The Republic" says, "Democracy is a charming form of government, full of variety and disorder, and dispensing a kind of quality to equals and unequal alike". One basic truism that permeates each of these definitions or any definition of 
democracy for that matter is that if truly analyzed and, it should be, a representative government in which the people through elections freely choose those who will represent and govern them all.

What Nigerian political leaders refuse to understand is that establishing sustainable democracy in Nigeria require more than creating structures such as executive, parliaments, courts, electoral commission and other institutions to oversee the rule of law and elections. To Sawyer (2004:109) apart from creating the above mentioned institutions, democracy must be grounded in certain values, among them acceptance of the common humanity of all citizens, acceptance of diversity as an asset indicative of the richness of human endowments, tolerance, and the building of social trust guided by accepted rules. Sawyer emphasizes that though, these values may not be dominant, these values are present in some form in most cultures of the world.

Democracy provides a veritable platform for the entrenchment and consolidation of good governance through institutional arrangements, citizen participation (Held, 1993: 24; Leke, 2010; Ghali, 1995: 6). However, with the above explanation of the concept of democracy, the ongoing democratic experiment in Nigeria, since May 1999, is yet to endanger good governance, as a result of increasing rate of poverty that rose from 17.7 million in 1980 to 34.7 million in 1985, 67.1 million in 1996 and over 70 million in 2004 (Omotosho, 2004: 17). This is coupled with the high rate of unemployment, inflation, deteriorating social institution and structures, as well as increasing population, which is due, basically to the specific policy choices and strategies pursued by the Nigerian government. These include deliberate withholding of resources, both fiscal and juridical, from states and local entities for political and ideological reasons, a turbulent economic and policy environment which has undercut local institutions; (World Bank, 2004: 1-2).

\section{Theoretical Framework of Analysis}

Dualism provision is the veritable tool of analysis in this paper. Dualism is a phenomenon of two constructing conditions. Within development though, dualism is implicit in structural change theories and exploit in international independence theories (Todaro, 1985). Dualism manifests as economy and social division in an economy. For instance, we can have differences in the degree of geographic development among others and it can be imposed or imported. No matter the source, dualism creates sharp differences that result in crisis and wars. Particularly, if it is politically engineered, the tendency to dominate the less privileged in the society by the politically and economically powerful groups conflicts with the need for independence and to be a master of one's life in the oppressed. Hence wars and other social crisis (Todaro, 1985).

Todaro further contended that there is a co-existence of small group of "progressive" wealthy elites with masses of traditionally oriented poor. Governance in Nigeria is comprised of the so called progressive and wealthy few who constitute the political class. Here the political machinery is a tool for corruption and perpetuation of personal gains (Idisi, 1999). The foregoing presupposes that upon identifying "the components of the situation", the next thing was to find the most effective way to resolve the identified problem. Further dualism applies 
also to the internal economies of Nigeria. For instance, there are great variations in the standard of living among the populace, majority of those with high incomes lives in urban areas while the poor live in rural areas. Under such conditions, if rural poor people become sufficiently knowledgeable that their plight is not God made and that it can be redressed, anarchy and crisis become imperative. For instance in Nigeria, we have well developed oil/gas companies' estates and factories sharing boundaries with villages and slums. Such development possesses the capability to induce war and agitations for egalitarian restructuring. The former existence is desired from the later hard work resources.

\section{Governance In Nigeria Is An Indicative Of The Following:}

\subsection{Corruption}

Corruption is a global phenomenon that is not only affecting the poor but also the rich. The Transparency International in her annual rating made Nigeria third in 2003, fourth in 2004 and fifth most corrupt nation in the world in 2005. Corruption now goes side by side with governance in Nigeria. General Abacha was said to have stolen more than $\$ 3$ billion between 1993 and 1998 (Falola, 1998: 208). Cumulatively, Nigeria leaders, according to the Economic and Financial Crimes Commission (EFCC), had within the last 43 years stole a total sum of $\$ 500$ billion (Amalu, 2006: 1). Corruption has eaten deep into the fabric of the nation and has shaken it to its foundation.

Many researches by the World Bank and experts in the field have shown that the problem of corruption is neither limited to the developed societies of the world nor the developing ones. The implication of this is that every known human society on earth has experienced one form of corruption or the other (Campos and Pradham, 2007).

Former President of the World Bank Group, Paul Walfowitz, asserts:

Corruption is a disease that threatens the hope of the poor: for a better future for themselves and their children. It drain finances that might otherwise go to programmes that brings education within the reach of the poor children, or that offer health care to an ailing or a young mother (Walfowitz, 2007: XI).

Corruption is the abuse of public office for private gains (World Bank, 1997). What this implies is that corruption entails abuse of one's office done to achieve either economic gains or nepotistic interests. Even favour done to a member of one's ethnic group has been included in this definition (Adisa, 2010: 201).

Mungiu-Pippidi (2006), argues that corruption could have a devastating effects on a country's economy. Its effects on politics and the political life of the citizenry may be staggering. In a country where corruption has become a social organization rather than being just an infringement of a public integrity, conducting free and fair elections tends to be very difficult. A good reason for this is that both the state and the political class are the actual participants in 
corruption. Thus, the state which is supposed to provide good leadership for ensuring free and fair elections, may be engross in corrupt practices, thereby finding it difficult to control its apparatus designed to conduct free and fair election, that is a genuine electoral system.

\subsection{Democratic Dictatorship}

The long period of military rule in Nigeria resulted in the centralization of power by pushing decentralization aside and the personalization of political power. This centralization and personalization of political power has manifested significantly under the democratic governance. The transfer of power from military regime to democratic regime rather than resulting in democratic governance is such that it is best described as 'dictatorship' as elected leaders in the country exhibit military traits and values in governance. Most guilty of these charges is the former President Olusegun Obasanjo, while in power he assumed the position of 'Controller General' of the whole universe; and 'Alpha and Omega' in governing the country. To the ex-President he was dubbed "impatient, unforgiving spirit, intemperate and often dictatorial". Soyinka observed that, democracy has been openly, blatantly and contemptuously rubbished by Olusegun Obasanjo (Soyinka, 2005: 1).

Violence and political intolerance have now become the hallmark of politics. Man has returned to those times referred to as the dark ages. The processes of interest reconciliation and consensus building have been substituted with wanton and brazen disrespect for life (Mato, 2005: 114). There has always been the use or the threat of violence within and between parties and candidates. The ultimate prize is the capture and retention of political power at all costs. Thus by implication the practice and nuances of democracy have never been allowed to germinate in the country (Leke, 2010: 36).

Political godfathers have taken over politics, causing it to change from what it used to be in the 60 's. Politics is now all about patronage and endorsement by the political godfathers. This act is practiced both by the ruling party and the opposition parties. Godfatherism in this sense according to Leke (2010: 36) means the practice of political office seekers getting connected to an individual who is believed to have the ability to deliver desired outcome in electoral contest. It is the intention of the godfathers to rule by proxy. The duo relationship (godfathers and godson) is not free floating, it is contractual, and is sometimes written and even sealed spiritually with an oath, or at the extreme, in a shrine. Examples of godfathers and godson swearing to an oath are many in Nigeria today, Emeka Offor and his godson Chinwoke Mbadinuju 1999-2003; Chris Ngige and his godfather Chris Uba 2003-2006; Orji Uzor Kalu and his godson, Theodore Orji 2007-2011). They dispense violence freely and fully to those who stand in their way; in this they play the additional role of warlord (Ayoade, 2006: 83). Godfatherism reduces the extent of legitimacy of government and destroys the electoral value of citizens.

\subsection{Economic Woes and Decayed Infrastructural Facilities}

This could be explained in the culture of profligacy arising from the low level of accountability that characterized governmental administration resulting in unbridled corruption, borrowing from international market, monetary instability, fiscal and especially 
investment policy, general climate of political instability, global economic meltdown as well as the problem of limited participation by the public in the formulation of economic policies and the strategies for implementing such policies (Leke, 2010: 37).

These abysmal economic failures culminated in serious infrastructural decay to the extent that most institutions of government were not working to expectation. A close look at some key infrastructure such as transportation, communication, electricity and water supply, education and health for example are regarded as the most turn around sectors of any economy in the world today. For example, electricity which is also part of energy is very important for economic development. This is because electricity is a way of improving the performance of almost all sectors of the economy i.e a critical input in agriculture, industrial and commercial production (Ukpong, 1996).

As important as the above to every human condition, most of the mentioned infrastructure remained in a state of disrepair, inspite of many financial costs to many firms outside the country. The dilapidation of the road network and the virtual collapse of the railway took both on intra and interstate economic transactions. Consequently, the economy remains as it is today grossly mono-cultural and distorted and depends on rents paid by the multinational oil companies which continued to mine oil in the volatile Niger Delta and thus, assured the state of access to a modicum of revenues in foreign exchanges. The Nigerian economy has remained limp for over three decades. Our mono-cultural economy remains a dumping ground for imports from abroad, while the national competitive index remains low in the face of widely spread inefficiency (The Guardian, October 1, 2009).

Today, the Nigerian economy is in shambles and remains non-productive, mono-cultural with collapsed infrastructure. If one were to cast his mind back from 2015 to 1960, one would discover that each decade was worse than the previous one. In 1960, one Nigeria Pound had the same value with one British Pound. Even up till 1980, one American dollar was less than one Nigeria naira. Today (January, 2018) one American dollar is exchanged for three hundred and sixty naira at the parallel market! Most painful of the whole situation is that as the value of the naira went down, so did the living conditions of Nigerians (Akinboye and Fadakinte, 2010: IX).

While the Babangida and Abacha regime has been carpeted for encouraging corruption on a large scale, the Goodluck Jonathan's administration has, in recent time, been labeled as the worst in Nigeria. During the Goodluck Jonathan administration, there was another twist to the looting of the national treasury. The administration was reported to have adopted another 'modus operandi'. Instead of packing the looted funds in 'Ghana Must Go' and transferring such illegal loots into secret bank accounts in Nigeria, it was speculated that money was moved in dollars and air lifted to countries overseas for onward banking in foreign accounts. This was happening at a time when majority of Nigerians were languishing in poverty.

The above confirm the positions of Marenin Otwin (1987) and Ake (1996) that the line demarcating politics and economics in Nigeria has been erased, because state power equals wealth, and wealth is the pathway to political power in the country. It also helps to explain how some people get into politics for personal and selfish gains (personal aggrandizement), 
instead of genuine democracy and good governance for the generality of the populace.

The late Nigerian President Umaru Musa Yar'Adua's administration was focused on the possible arrival on the shelf of the vision 2020 document as a major achievement. The administration pins its exaggerated hopes for the economy on the agglomeration of projections. However, government will do well to ponder the fate of the four National Development Plan (1981) and its successor Structural Adjustment Programme (SAP), several three year rolling plans including their variant medium term expenditure frameworks, NEEDS (2004) and indeed the annual budgets down the years, all which were neutralized by the corrosive effect of a mismanaged economy (The Guardian, October 1, 2009).

The Heritage Foundation and The Wall Street Journal, two influential organizations based in the United States, ranked Nigeria $146^{\text {th }}$ out of 157 countries listed for assessment on economic growth. In Sub-Saharan Africa, the report rated Nigeria above only one country Zimbabwe. And this is inspite of the fact that Nigeria makes over $\$ 80$ billion (or over 10 trillion naira) per annum, from oil alone (The Guardian, October 1, 2006). With all these earnings, the standard of living of the average Nigerian continues to plummet as the per capita income based on purchasing power parity (PPP) remains about PPP\$ 1,050. In Malaysia, the same figure is PPP\$9,512, while in South Africa, it is PPP\$10,346. Over 87 percent of Nigeria lives below the poverty line (The Guardian, October 1, 2006).

Thus, the promising country at independence in 1960 has today become a caricature of a nation unable to feed her citizens and provide other basic social services like education, health and security. Nigeria now faces soaring unemployment that has leads to uncontrollable crimes.

\subsection{The Process of Governance and Good Governance in Nigeria Today}

Efforts to improve governance in Nigeria have been conceptualized as quest for good governance. At the middle of the concept of good governance is the idea that accountability, transparent, and inclusive governance is both the best promoter and the best producer development. Good governance embodied three domains of governance: the government, the private sector, and civil society. These three strives o ensure collaboration among them.

To Sawyer (2004), good governance initiatives are designed to improve governance competence and measure should be taken to strengthen all aspects of governance.

Good Governance has been described as participatory, consensus oriented, accountable, transparent, responsive, effective and efficient, equitable and inclusive and follows the rule of law. It also ensures that corruption is minimized, the views of the minorities are taken into account and that the voices of the most vulnerable in society are heard in decision-making. It is also responsive to the present future needs of society (Fadakinte, 2013).

To Diamond (2005) good governance consists of several dimensions, some of which are, the capacity of the state to function, the commitment of elected officials to the public good; transparency, accountability; the rule of law and well established mechanism for conflict resolution. Against the above, democracy impacts positively on good governance as a result 
of the empowerment enjoyed by citizens through the instrumentality of democracy to make good governance available.

Governance in today's Nigeria has portrayed and presented a mockery of the widely acclaimed symptom of good governance; democracy the official governmental practice has been hijacked by criminal and corrupt apologies to the extent that citizens now experience despair instead of hope, terrorist attacks instead of protection, insecurity instead of security, tragic and unfortunate death instead of long life and high life expectancy.

In terms of welfare of citizens, the performance of Nigeria is below expectations. If commitment to public good by efficient delivery of services to the people for the enhancement of the citizens' welfare is what defines good governance, then the last eighteen years has witnessed nothing but bad governance which breeds social vices in the society (Fadakinte, 2013).

There is a dialectical nexus between leadership, governance, good governance and the quality of life available to Nigerians. The elite corps which the colonial milieu fostered five decades ago is all but wasted now. The years of military commandist rule and disregard for accountability have made a virtue of corrupt acquisition and brigandage. With kleptocracy as its doctrine, the elite have failed to convert Nigeria's enormous providential endowments into material assets for the impoverished population. Class differences are exacerbated as consequences, with the mansions of the rich looking more like feudal castles. The truth is that the quality of life of the average citizen today has declined below the standard of the least endowed at the time of independence (The Guardian, October 1, 1998).

One of the key issues in the 60s was the need to ensure unity in diversity among the various ethnic nationalities (The Guardian, October 1, 1999). Today, sectarian and religious identity is as sharp as a newly acquired cutlass, as each group resides out of the centre to the ethnic periphery. Some groups have even dovetailed into using terrorist attacks against innocent citizens to drive their agitations home. Various social groups are questioning the basis of Nigerian union. The idea of federalism also seems to have been subverted. The life of an average Nigerian as it is in the present conditions of the country; approximates the practical demonstration of the Hobbessian type, which is solitary, nasty, brutish, and short as cases of unresolved political and terrorist killings are growing by leaps and bounds.

Security wise, law and order have practically broken down, as kidnapping, armed robbery and low intensity insurgency pervades the country. The serial bombing and terrorist attacks by the Boko Haram sect has made nonsense of security in the country and portrayed an atmosphere of siege. In the 2011 general elections, more than 800 lives were lost in post election violence (The Guardian, October 1, 2011). All these can be attributed to failure of governance and the deepening poverty.

\section{Conclusion/Recommendations}

Governance as a process has impacted negatively on the Nigerian populace. This is as a result of the dreaded disease that seems to always inflict its leadership. This disease is called corruption, combined with primitive accumulation of wealth. The conclusion drawn from this 
paper is that a general reconstruction is required. There is a need to rebuild the bridges between the state and the people who are being governed by the state, empower the people and strengthen the state.

Presently, the Nigerian State is in a flux because the dominant class is in factional crisis and is unable to organize itself to be united with a common ideology needed to plan for development, as a result, the Nigerian society is thrown into a condition, making everybody to run helter shelter for survival, which is gradually turning the Nigerian State into the Hobbessian state of nature (Fadakinte, 2015). And the situation is like that because, Nigeria as a state has a very weak institutions. Based on the above how does the Nigerian government plan for development, good governance and organized leadership for its teeming citizens, when a sizeable portion of its budget is channeled to defence, to enable its secure political order and provide for political stability so as to be able to maintain social control.

Nigeria's governance agenda must strive from the start not only to install good governance but also to develop democratic governance. Democratic governance requires that governed citizens themselves become governors determining their own future and not simply be beneficiaries of goods and services provided by governments. The preparation of citizens for decision making and the crafting of governance institutions that repose governance authority in a knowledgeable citizenry are the hallmarks of a democratic society. This require going beyond the strengthening of parliaments and electoral processes and other democratic institutions at the level of the central government. Democratic governance requires removing governance constraints that create sub citizen jurisdictions for rural people, women, and minorities.

In achieving these, a starting point should be the country's infrastructures which are lamentably in disarray. First is the political infrastructure both in terms of the bureaucracy, the arrangement of political institutions and ideology of governance. Second, is the social infrastructure? Nigeria is 57 years old, but its educational institutions are poorly equipped, its teachers are demoralized, there is no Nigerian university ranked among the first 1000 in the world. At a time when most universities in other parts of the world are in the computer age, using computer technology in teaching, our own universities are still using moribund equipment.

Third, is the economic infrastructure? We live, in the age of economics. The $21^{\text {st }}$ century is bound to be even more challenging with the reality of globalization, international finance and statelessness of capital. Nigeria must be part of the future, and not remain bogged down by the limitation of the past.

Positive leadership translates to honesty, accountability, respect for the rule of the land, selfless service to the people at all levels of governance. There is equally the need to stem the role of corruption at all levels of governance which has been perceive as one of the greatest impediments to good governance and to enable sustainable development. While this paper encouraged the present administration to continue on its fight against corruption, the paper also recommends that good governance structures that are rooted in constitutional law be created, good governance structures that truly devolve governance authority, including the 
authority to mobilize and dispense resources to local communities.

\section{References}

Achebe, C. (1983). The Trouble with Nigeria, Oxford: Heinemann.

Adisa, W. B. (2010). From 'Kickbacks' to Ghana Must Go: A Discourse on the Political Economy of Rent-Seeking in Nigeria, in Akinboye, S.O and Fadakinte M.M. (ed): Fifty Years of Nationhood? State, Society and Politics in Nigeria (1960-2010). Concept Publications, Lagos.

Ake, C. (1991). Rethinking African Democracy. Journal of Democracy, 2(1). https://doi.org/10.1353/jod.1991.0003

Ake, C. (1996). For Africa, the Way Forward. The Guardian, Lagos: November 13.

Ake, C. (1996). The Political Question. In Oyeleye Oyediran (ed) Governance and Development in Nigeria: Essay in Honour of Professor Billy Dudley, Ibadan: Oyediran Consults International.

Akinboye, S. O., \& Fadakinte, M. M. (2010). 50 Years of Nationhood? State, Society and Politics: (1960-2010). Concept Publication, Lagos.

Amalu, C. (2006). Over N60 Trillion was Stolen by Nigerian Past Leaders - EFCC”, Vanguard, Lagos Vanguard Newspaper Limited. October 17.

Ayoade, J. A. (2006). Godfathers Politics in Nigeria, in Money, Politics and Corruption in Nigeria. IFES.

Campos, E., \& Pradhan, J. (2007). The Many Faces of Corruption; Tracking Vulnerabilities at the Sector Level. Washington D.C.: The World Bank. https://doi.org/10.1596/978-0-8213-6725-4

Dauda, S., \& Liman, A. (2005). (ed): Issues in Nigeria's Political and Economic Development. Zumuta Publishers, Abuja.

Diamond, J. (2005). Democracy, Development and Good Governance. The Inseparable Links. Lecture at Ghana Centre for Democratic Development, Accra.

Fadakinte, M. M. (2013). Civil Society, Democracy and Good Governance in Nigeria: (1999-2012). International Journal of Modern Social Sciences, 2(2). 133-154.

Fadakinte, M. M. (2015). State and Society in Africa: An Exploration of African Development Crisis. Scotish Journal of Arts, Social Sciences and Scientific Studies. Vol. 25, Issue 1.

Falola, T. (1999). The History of Nigeria. London Greenwood Press.

Fanon, F. (1967). The Wretched of the Earth. NY: Grove.

Gauba, O. (2003). An Introduction to Political Theory. Fourth Edition. Rajiv Beri for Macmillan Indian Press.

Ghali, B. (1995). Democracy: A Newly Recognized Imperative, Global Governance. Goetz and Gaventa (2001).

Held, D. (1993). Democracy: From City-States to a Cosmopolitan Order. In Held, D (ed) Perspective for Democracy, Cambridge Policy Press.

Idisi, P. O. (2005). Resource Control in Nigeria's National Question: A survey of theories and views. In Dauda, S and Liman, A (ed): Issues in Nigeria's Political and Economic Development. Zumuta Publishers, Abuja.

Leke, O. (2010). Democracy and Governance in Nigeria's Fourth Republic. African Research 
Review: An International Multi-Disciplinary Journal Ethiopia, 4(3a).

Marenin, O. (1987). The Anini Saga: Armed Robbery and the Reproduction of Ideology in Nigeria. Journal of Modern African Studies, 54(1). https://doi.org/10.1017/S0022278X00000380

Mato, K. (2005). Developing Viable Democratic Culture Through the Electoral Process, in Dauda, S., \& Liman, A. (ed): Issues in Nigeria's Political and Economic Development. Zumuta Publishers, Abuja.

Mungiu, P. A. (2006). Corruption: Diagnosis and Treatment. Journal of democracy, July, 17(3). https://doi.org/10.1353/jod.2006.0050

Oke, L. (2005). Globalization, Democracy and Women Empowerment: Issues and Challenges in Nigeria. In Olufayo, O. O. (ed): Perspective On Globalization and African Development, Lagos. Badagry Publications.

Olanipekun, W. (2004). The Search for good Leadership: The Guardian, Tuesday, June 4.

Olukoju, A. (2013). Nigeria's Cultural Tapestry and Development. A Paper Delivered at the Nigeria Academy of Letters 2013 Convocation Lecture.

Omotosho, G. (2004). Cock-Crow for Civil Service. The Comet, Wednesday, June 30.

Rodney, W. O. (1972). How Europe Underdeveloped Africa. Tanzania. Tanzania Publishing House.

Sarantakos, S. (2005). Social Research (Third Edition). Melbourne, Macmillan Educational Press. https://doi.org/10.1007/978-0-230-20901-5

Sawyer, A. (2004). Governance and Democratization. In Adebajo, A., \& Rashid, I. (ed) West Africa's Security Challenges: Building Peace in a Trouble Region, Lynne Rienner Publishers, Colorado, USA.

Soyinka, W. (2005). Soyinka Knocks Deal on Lagos Funds; Rule of Law Endangered" in the Comet, August 24.

Stodgill, R. M. (1981). Handbook of Leadership: A survey of Theory and Research. New York: The Free Press.

The Guardian, October 1, 1998.

The Guardian, October 1, 1999

The Guardian, October 1, 2006.

The Guardian, October 1, 2009.

The Guardian, October 1, 2011.

Todaro, M. (1985). Economic Development in the Third World. Third Edition Longman. New York.

Ujomu, P. O. (2004). Development Institutions Participation and the Problems of Social Engineering in an African Nation-State, in Ajayi, K and Ayodele, B (ed): Perspectives on Democracy and Development in Post-Military Nigeria. Ibadan, Julius and Julius Associates.

Ukpong, I. I. (2006). Social and Economic Infrastructure of Nigerian Economy; Lagos; Macmillan Press.

Wolfowitz, P. (2007). Forward. In Stapenhurst, Rick; Johnston, Niall and Pellizo, Ricardo. The Role of Parliament in Corruption in Curbing Corruption. Washington D. C.: The World Bank.

World Bank. (1997). "The State in Changing World". Retrieved from 


\section{Macrothink}

Journal of Public Administration and Governance ISSN 2161-7104 2018, Vol. 8, No. 1

http://openknowledge.worldbank.org/handle/10986/5980.

World Bank. (2004).”Nigeria State Governance Work”. Report No. AR592 RetrievedFrom http://www.worldbank.org/infoshop.

Yagboyaju, D. A. (2010). Fifty years, the Search Continues: A Critical Analysis of Some Contending Issues in Nigeria's Leadership Question, in Akinboye, S. O., \& Fadakinte, M. M. (ed): Fifty Years of Nationhood? State, Society and Politics in Nigeria (1960-2010), Concept Publications, Lagos.

Yahaya, A. D. (1999). Public Service and Good Governance, in the Guardian, Friday, June 4.

\section{Copyright Disclaimer}

Copyright for this article is retained by the author(s), with first publication rights granted to the journal.

This is an open-access article distributed under the terms and conditions of the Creative Commons Attribution license (http://creativecommons.org/licenses/by/4.0/). 